\title{
Minutes of August 2017, APSA Council Meeting
}

\author{
Wednesday, August 3o, 2017 \\ San Francisco, CA \\ Hilton Union Square
}

\section{MEMBERS PRESENT}

President: David Lake; Past President: Jennifer Hochschild; President-Elect: Kathleen Thelen; Vice President: Janet Box-Steffensmeier; Vice President: Ian Shapiro; Secretary: Marion Orr; and Treasurer: Taeku Lee

Council Members: Matt Barreto, Mark Crescenzi, Omar Encarnación, Roxanne Euben, Kristian Gleditsch, Juliet Hooker, Amaney Jamal, Brett Ashley Leeds, James Mahoney, Byron D’Andra Orey, Bo Rothstein, Cameron Thies, Caroline Tolbert, Renée Van Vechten, and Christina Wolbrecht Guests: Joseph Carens, Gary Segura, Rogers Smith

APSA Staff: Steven Rathgeb Smith, Betsy Super, Kara Abramson, Dan Gibson, Kimberley Mealy, Jon Gurstelle, Rory Jackson, Helen Marshall, Meghan McConaughey, and Teka Miller

Not in Attendance: Vice President: Elaine Kamarck; and Colleen Shogan

\section{INTRODUCTION}

APSA President David Lake calls the meeting to order at 8:30 a.m.

\section{CONSENT AGENDA}

Lake moves to approve the Spring council meeting minutes. Motion is seconded and unanimously approved.

\section{TREASURER'S REPORT}

Treasurer Taeku Lee introduces the treasurer's report to update the council on the association's financial position. Lee reports that APSA continues in a sound financial state. At July 31, 2017, the total fair market value of all APSA investments was \$36.27 million. The most significant investments groups are the Trust and Development Trust Portfolio, which totaled \$16.24 million, and the CFP Trust Portfolio, which totaled $\$ 16.29$ million, as of July 31,2017 . APSA is projected to be in line with budget. At nine months ending June 30 2017, APSA is projecting revenue of $\$ 7.6$ million from operations and $\$ 6.9$ million from operating expenses resulting in a projected operating net profit for year-end of $\$ 689$ thousand. The projection includes budgeted draws/fund transfers of \$822.2 thousand and projected 2017 Annual meeting net profits of $\$ 583$ thousand. The full report was provided in the Council Book and there will be a vote on the budget at the end of the meeting.

\section{PRESIDENT'S REPORT}

Lake reports on the council's and association's developments and accomplishments over the past year to update the council on the state of the association. Lake discusses the implementation of the new bylaws, which took effect with the summer's council election; the implementation of the new anti-harassment policy, including the introduction of the ombuds program at the Annual Meeting; the updates to the Teaching and Learning Conference; the progress of his task forces on financial conflict of interest and human subjects research; and the continuing work of the qualitative transparency deliberations.

\section{EXECUTIVE DIRECTOR'S REPORT}

Executive Director Steven Rathgeb Smith introduces the executive director's report to update the council on developments in the association. Smith provides updates on the governance reform process; implementation of the strategic plan; increased investment in travel and research grants; international programs; APSA staffing; the APSA website and discussion platform; recent editorial transitions and other ongoing publications issues; and diversity and inclusion programming, including the Ralph Bunche Summer Institute (RBSI). He also notes that the attendance at the 2017 Annual Meeting is expected to be very strong. Smith notes that upcoming projects include plans to work with the ethics committee to update the ethics guide and an assessment of the APSA membership strategy and dues structure. The council discussed APSA membership trends, including retention rates; membership types; and outreach to different types of political scientists, including non-faculty and community college faculty.

\section{FINANCES AND INVESTMENT}

Lake introduces discussion of APSA finances and investments for the purpose of council discussion and approval of a plan for surplus expenditures and investment management. Lake summarized the Executive Committee discussion from June, which reviewed the APSA budget and recommended that the 2017 budget presented to the council should be balanced rather than planning for a small surplus. An annual 4.5 percent draw is taken from the endowment and put into the operating budget and, historically, any surplus has been reinvested. At $\$ 36$ million, the Executive Committee believes the endowment to be sufficient and planned surpluses should be eliminated. The budget presented to the council was revised to eliminate the surplus by allocating additional funds to travel and research grants. In the future, APSA staff will continue to budget conservatively but will present budgets without a planned surplus.

Even with a planned balanced budget, variation in revenues, particularly from the Annual Meeting, may lead to a surplus at the end of the fiscal year. The Executive Committee suggests that, rather than reinvesting any surplus into the endowment, the council should decide how to spend any additional funds. Options for spending any surplus include increased funding of research and travel grants, increased support of RBSI or the Minority Fellows Program (MFP), or creation of a special projects fund.

Leeds provides more detail on the idea of a special projects fund, which would include a call for project ideas from membership, with guidelines and strict criteria to ensure suggestions serve APSA membership as a whole, and review by the Executive Committee and/ or the council. Several council members suggested that surplus funds should be directed toward additional travel grant funding for graduate students, international scholars, or even nonacademic political scientists. While funding for travel grants has been increased, they are still relatively modest.

An ad hoc committee to examine how to spend any surplus is suggested, but Lake notes that under the current governance structure those decisions are the responsibility of the Executive Committee. Lake moves that the Executive Committee be empowered 
to allocate any FY 2016-17 surplus, based on input and proposals provided by APSA staff, and instructed to report the results of this process to the full council at its spring 2018 meeting. The motion is seconded and approved unanimously.

Lake then opens discussion on forming an investment oversight committee to oversee APSA's investment strategy, for the purpose of council approval. While budgeting and overall financial responsibilities will remain with the council and Executive Committee, having a small committee focused on APSA's investment strategy would assist the Executive Committee and could allow APSA to do without an investment advisor. Smith notes that, while the endowment is passively invested APSA still pays an investment advisor $\$ 45,000$ per year. Jamal enquires about whether APSA invests ethically, and Smith and Lake note that APSA is not currently ethically invested but there has been discussion of working toward ethical investments. An investment oversight committee could also be helpful in moving forward on that issue. Mahoney moves to approve the creation of a small investment oversight committee, to include the APSA treasurer, to oversee investment strategy and portfolio balance. Motion is seconded and approved unanimously.

\section{PS EDITOR REVIEW AND RENEWAL}

Lake opens discussion of the PS editor review and renewal for the purpose of council discussion and approval. Leeds, chair of the Council Publications Policy Committee, notes that the committee recommends renewing the $P S$ editorial team's term for a four-year extension (through 2022), based on the review committee's report. Leeds and Wolbrecht, who served on both the Publications Policy Committee and the PS editors review committee, explain that metrics of journal stewardship and evaluations of vision and enthusiasm suggest positive leadership by the editors, though the review committee had concerns about clearly indicating which articles are peer reviewed and encouraging diversity in symposia. The Publications Policy Committee suggests that the editorial team be asked to specifically address progress on encouraging diversity in symposia in their annual report to the council. Orr and Encarnación ask for clarification on the issue of diversity in the PS symposia. Wolbrecht and Leeds note that the issue was not systematically studied, so the actual effective diversity was unclear; however, the process for developing symposia does not encourage diversity and, because it is based on existing networks, could lead to underrepresentation of women and minorities. When asked about the diversity issue, the editors did not provide a clear answer for how they would encourage diversity in symposia. Gleditsch and Euben note that while the editors did not have a clear proactive answer for encouraging diversity in symposia, they did ask for direction from the committee and were willing to address the issue. Orr indicates his support for the four-year renewal, but notes that it should be made clear to the editorial team that symposia diversity issues must be proactively taken into account in a serious manner. PresidentElect Kathleen Thelen suggests that the editors be specifically asked to address concerns about diversity in their annual report. Lake moves to approve the renewal of the $P S$ editorial team's term for four years, through 2022, with explicit instructions to address diversity in symposia in the $P S$ editors' annual report to the council. Motion is seconded and approved unanimously.

\section{JOURNAL DATA COLLECTION}

Lake introduces discussion of the Council Publications Policy Committee proposal regarding implementation of the new journal data collection policy, for council discussion and approval. Leeds notes that at its April meeting the council approved a journal data collection policy to increase systematic data collection regarding submissions to APSA journals, particularly to gain a better understanding of the diversity of what is being submitted and published. The Publications Policy Committee has now worked with editors, authors and reviewers to develop an implementation plan, as outlined in their memo. Lee suggests that questions regarding race and gender be placed at the end of the questionnaire, and that the question on race should allow for multiple responses. Leeds and Wolbrecht agree and accept the change in format to the race question as a friendly amendment. Lee also suggests adding an "other" option for the question about the submission's primary methodological approach. Leeds expresses concern that this change might limit how informative the data would be. Lee, Thelen and Hochschild suggest other approaches to the question regarding methods but no clear consensus is reached. Tolbert emphasizes the importance of a clear disclaimer about the anonymity of the responses. Lake moves to accept the committee recommendations, as amended. The motion is seconded and approved unanimously.
FINANCIAL CONFLICT OF INTEREST POLICY

Lake introduces the proposed financial conflict of interest policy, for the purpose of council discussion and approval. Lake notes that the proposal has been drafted by one of the committees of his presidential task force, and focuses specifically on financial conflicts of interest. Lee suggests that the policy should exclude disclosure of honoraria from academic appearances. Jamal and Segura expressed concern that disclosure in the review process could penalize scholars with limited research funds, who need outside funding, or graduate students who may have worked for and gotten data from NGOs or governments. Barreto notes that providing disclosure information to reviewers could also cause an issue with blind review, as some disclosures could reveal an author's identity. Orr inquired about policies at other associations, and Lake noted that APSA is the only major academic association that he knows of without a financial conflict of interest policy. Lake also notes that the issue of disclosing conflicts of interest early or late in the review process is complex and requires trade-offs. The council agrees to refer the proposed policy back to the committee with comments.

\section{SITING POLICY}

Lake introduces discussion of the proposed revised siting policy, for Council discussion and approval. Vice President Ian Shapiro, chair of the Council Meetings and Conferences Policy Committee, outlines the proposed siting policy, noting that it has been streamlined but does not introduce any major policy change. He notes that the committee accepted the proposed siting policy without the need for discussion and are now bringing it before the full council. Barreto, Euben and Encarnación discuss the implications of states prohibiting the use of state money to travel to specific other states. Shapiro noted that most of the currently relevant states would be covered by the siting policy, but it is difficult to plan for all eventualities. Leeds offers a friendly amendment to replace any reference to "holding" the meeting with the language "siting" the meeting, because meetings must be planned well in advance and circumstances may change between siting and holding the meeting. The committee accepts the amendment. Lake moves to accept the committee's proposed siting policy, as amended. Encarnación seconds the motion and it is approved unanimously. 


\section{APSA CONNECT}

Dan Gibson of the APSA staff provides a demonstration of the updates made to APSA Connect, which is now on the open source WordPress platform.

\section{APSR EDITORIAL TERM}

Lake introduces discussion of the APSR editorial team's term and possible review for council discussion. Lake explains that after extensive council discussion surrounding the originally proposed editorial team, the current editorial team was offered a three-year term to begin in 2016, with the possibility of renewal for an additional three-year term. The review process for renewal would need to begin in fall 2017, however this review would be based on only one issue published entirely under the current editorial team. The Executive Committee proposes extending the APSR editorial team's term for one additional year, to 2020, with the possibility of a two-year renewal at that time.

Encarnación, Mahoney and Jamal express concern that the original issues that led the council to offer a three-year term rather than a four-year term have not been addressed. Jon Gurstelle, APSA Publications Director, reports that while the team has been in place less than a year, the basic metrics for assessing performance are good, as submissions have increased, the average time to decision has decreased, the team is publishing on time, and has introduced a Firstview workflow. Shapiro notes that it would be difficult not to renew the team based on only one issue, and that the conservative approach may be to extend their term now and allow for a more in-depth review in a year. Shapiro also notes the difficulty in finding interested editorial teams, and notes that extensive oversight may be driving some of the difficulty. The council may want to consider that when deciding the appropriate level of oversight. Thelen agrees, and notes that the Publications Policy Committee is considering reasons for the difficulty in recruiting editorial teams, but that some measure of oversight is important. Lake moves to extend the term of the APSR editorial team for one additional year, through 2020. The motion is seconded and approved unanimously.

\section{SECTION JOURNALS}

Lake introduces discussion of section journals for purposes of council discussion.
Smith notes that under the current policies on section journals, sections are not required to get approval from APSA staff or the Executive Committee when agreeing to journal contracts. The Executive Committee proposes that new contract proposals must go through APSA staff and then be approved by the council, because APSA is financially liable for contracts signed by section journals. Orr, Jamal, and Encarnación discuss the scope of oversight and whether there should be any content oversight as well. Thelen notes that the Council Membership Policy Committee will be discussing section oversight generally. Lake notes that the current proposal is simply for financial oversight. Lake moves to require council approval for new section journal contracts. The motion is seconded and approved unanimously.

\section{SEXUAL HARASSMENT SURVEY}

Lake introduces Virginia Sapiro, chair of the Professional Ethics, Rights and Freedoms Committee to present the committee's report on the APSA Sexual Harassment Survey. Lee and others note the importance of making sure that this information is publically available. Sapiro indicates that the revised report will be published in $P S$ and will be available. Encarnación, Wolbrecht, Euben and Crescenzi discuss strategies for discouraging all-male panels, which were suggested in the open comments section of the survey. Sapiro notes that a number of steps have already been taken to address the issues highlighted by the survey, including the introduction of the ombuds program.

\section{AFFILIATED GROUPS AND \\ CONTROVERSIAL SPEAKERS}

Lake opens discussion of controversial and potential protests at the Annual Meeting for the purpose of updating the council. Smith explains that at least one controversial speaker on a related group panel has attracted attention and concern. Concerned members have been encouraged to attend the All Member Business Meeting and all attendees will be reminded of the code of conduct. Jamal, Euben and Hochschild note that this brings up questions about the role of the related groups and oversight for their panels. Thelen notes that the Meetings and Conferences Committee will be tasked with examining the role of affiliated groups, and possibly bringing forward a proposal to the council.

\section{POLICIES MANUAL}

Lake introduces the proposed additions to the governance policies manual for council discussion and approval. The policies include procedures for introducing resolutions and amendments, inspection of records, rules for revision of the policies manual, setting record dates, accepting electronic signatures, and providing materials to the council. These policies supplement and operationalize the bylaws. Lake moves to accept the proposed additions to the policies manual. The motion is seconded and approved unanimously.

\section{POLICY COMMITTEE UPDATES}

Lake invites policy committee chairs to provide any additional updates to the council. Van Vechten discusses developments in the Teaching and Learning Committee, included website changes to highlight teaching and learning resources, a survey on teaching and learning technology resources, and plans for the teaching and learning miniconference planned for the 2018 Annual Meeting in Boston. Plans for the coming year include exploring the possibility of producing video resources for teaching and learning. Orr reports that the Public Engagement Committee has focused on promoting the public presence of political science, including through a weekly roundup series on PSNow.

\section{EDITORIAL BOARDS}

Lake introduces proposed changes to the Perspectives and JPSE editorial boards for council discussion and approval. Following questions about the full composition of the Perspectives board, along with the proposed additions, discussion of the Perspectives board is postponed until a full list could be reviewed. Orr moves to accept the proposed JPSE editorial board. Lake seconds the motion and it is unanimously approved.

\section{APSA BUDGET}

Lake introduces the proposed APSA budget for council approval, based on the day's discussions. Orr moves to approve the budget. Lake seconds the motion and it is unanimously approved.

The meeting adjourned at 4:44 p.m. 